\title{
Physicochemical and sensory properties of deep fried battered squid containing Brownstripe red snapper (Lutjanus vitta) protein hydrolysate
}

\author{
${ }^{1}$ Chew, R.M., ${ }^{1}$ Mohd Zin, Z., ${ }^{2,3}$ Ahmad, A., ${ }^{1}$ Mohtar, N.F., ${ }^{4,5}$ Rusli, N.D. and \\ $1, *$ Zainol, M.K. \\ ${ }^{1}$ Faculty of Fisheries and Food Science, Universiti Malaysia Terengganu, 21030, Kuala Nerus, Terengganu \\ ${ }^{2}$ Faculty of Science and Marine Environment, Universiti Malaysia Terengganu, 21030, Kuala Nerus, \\ Terengganu \\ ${ }^{3}$ Institute of Tropical Biodiversity and Sustainable Development, Universiti Malaysia Terengganu, 21030 \\ Kuala Nerus, Terengganu, Malaysia \\ ${ }^{4}$ Faculty of Agro Based Industry, Universiti Malaysia Kelantan, Jeli, Kelantan, Malaysia \\ ${ }_{5}^{5}$ Institute of Food Security and Sustainable Agriculture, Universiti Malaysia Kelantan, Jeli, Kelantan, \\ Malaysia
}

\section{Article history: \\ Received: 26 February 2020 \\ Received in revised form: 29 \\ March 2020 \\ Accepted: 1 April 2020 \\ Available Online: 17 April \\ 2020}

\section{Keywords:}

Brown stripe red snapper fish protein hydrolysate,

Deep-fat frying,

Sensory analysis

DOI:

https://doi.org/10.26656/fr.2017.4(4).083

\begin{abstract}
Deep-fried food is a fast and convenient way to prepare food that imparts desirable sensory characteristics of colour, flavour and in particular, a smooth texture, yet has been labelled as not healthy by consumers. Incorporation of other ingredients in the formulation of the batter could reduce the fat absorption in deep-fried foods. This research was aimed to determine the physicochemical and sensory properties of Brownstripe red snapper protein hydrolysate $(\mathrm{BRSPH})$ and its utilisation in reducing the oil intake of deep-fried foods. The BRSPH were extracted using the enzymatic method utilizing Alcalase ${ }^{\circledR}$ as the working enzyme. Batter formulations were prepared by adding $0 \%, 2 \%, 4 \%, 6 \%$ and $8 \%$ of BRSPH into the sample mixtures. Addition of BRSPH into the batter was found to increase hardness and crispness of deep-fat fried battered squids. The fat content of the deep-fat fried battered squids with $8 \% \mathrm{BRSPH}$ powder was found to be the lowest compared to those added with $2 \%, 4 \%$ and $6 \%$, while sample without BRSPH powder was the highest (30.15\%). Deep-fat fried squids with $4 \%$ of BRSPH powder showed the best acceptability scores in terms of crispness, taste and overall acceptability, but no significant differences were determined in the crispness between deep-fat fried squids with and without BRSPH. The findings indicate that enzymatic hydrolysis using Alcalase ${ }^{\circledR}$ has the potential to yield BRSPH with a high degree of hydrolysis $(98.19 \%)$, low molecular weight (10-15 kDa), and low oil binding capacity (2.38 g oil/ g protein). Enzymatic hydrolysis proved to be a viable technique to produce protein hydrolysate which able to reduce the oil uptake and healthier with high acceptability of the end products. Research on how to optimize the use of BRSPH with a high economic, nutritional and industrial potential of understated resources would allow for the implementation of manufacturing practices to enhance the use of resources and increase the value of the by-product. This approach will offer the potential use of BRSPH for the production of batter formulation which is efficient in the reduction of oil uptake.
\end{abstract}

\section{Introduction}

Deep-fried food has become increasingly popular because it is fast and convenient which imparts unique sensory properties of colour, flavour and, in particular, the texture of a smooth, moist interior coupled with a crispy crust outside (Pedreschi and Moyano, 2005). However, customers are becoming more health- conscious and are increasingly turning to foods that are high in nutritional value and low in fat and caloric content. Moreover, fried foods also constitute high fat content, often exceeding $1 / 3$ of the total food by weight (Mellema, 2003).

In order to reduce the fat in high-fat fried products, surface treatments widely used to reduce oil uptake in 
deep-fried foods (Lumanlan et al., 2019). Surface treatment is the application of coating materials to the surface of food products to limit oil and moisture transfer during frying (Radwan, 2017). Soy protein isolate, whey protein isolate and methylcellulose were very effective in reducing oil uptake in deep-fried foods (Albert and Mittal, 2002). Most of the barriers used in the commercial production of fried foods are protein-based (Hau et al., 2018). Fish protein hydrolysate, such as striped catfish protein, was found to reduce oil binding capacity by increasing the degree of hydrolysis (Tanuja et al., 2014).

Snappers can be found in tropical and subtropical waters of all oceans. Snapper typically feeds on fish, crustaceans and molluscs, particularly squid. In Malaysia, three common types of snappers are available for consumption: red snapper (Lutjanus argentimaculatus) and golden snapper (Lutjanus johnii) (Rosmilah et al., 2005). Brownstripe red snappers (Lutjanus vitta) (Figure 1) can be used as an excellent raw material for the production of hydrolysate due to its low human consumption, which is considered as underutilized marine fish.

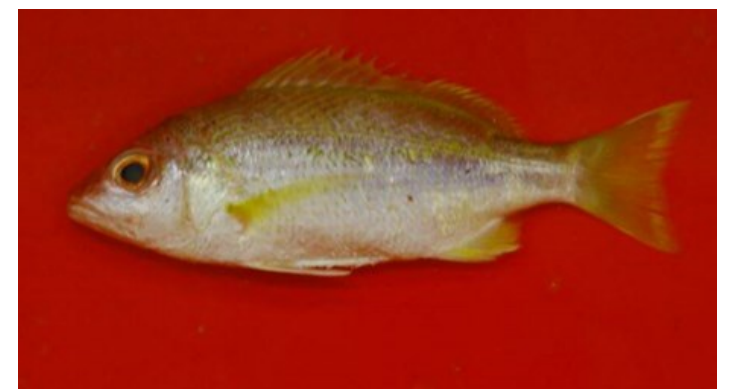

Figure 1. The Brownstripe red snapper (Lutjanus vitta)

It is suggested that fish protein hydrolysate with low oil-binding ability and low molecular weight may also minimize the fat intake of deep-fried foods (Zainol et al., 2020). Nevertheless, there is limited information on the use of Brownstripe red snapper hydrolysate protein (BRSPH) in reducing the consumption of deep-fried foods in oil. Successful results may serve as an initiative to enhance or develop a healthy fried food that has contributed commonly to obesity and chronic diseases. Thus, this study aimed to determine the effect of BRSPH on reducing the oil uptake in a fried product and to investigate the potential of BRSPH in the batter formulation as a good source of protein.

\section{Materials and methods}

2.1 Preparation of Brownstripe red snappers fish protein hydrolysate (FPH)

Brownstripe red snappers were purchased from Jeti Pulau Kambing, Kuala Terengganu, Terengganu,
Malaysia. The fish meat was subsequently homogenized in a food processor (Panasonic, Malaysia) and extracted according to the method of Hau et al. (2018). Fish meat of $50 \mathrm{~g}$ was deactivated for $10 \mathrm{mins}$ at $90^{\circ} \mathrm{C}$. The deactivated fish meat was then mixed with $100 \mathrm{~mL}$ pH 8 buffer. A total of $50 \mathrm{~g}$ of the homogenized deactivated fish meat was mixed with $500 \mathrm{~mL}$ of $90^{\circ} \mathrm{C}$ water for 10 mins. A further $50 \mathrm{~mL}$ of $1 \mathrm{M}$ potassium phosphate buffer ( $\mathrm{pH}$ 7.5) was added to the fish (ratio of 1:1 between fish and buffer) and the mixture $\mathrm{pH}$ was carefully adjusted to 7.5. After $3 \mathrm{hr}$, the mixture was heated for $5 \mathrm{mins}$ at $90^{\circ} \mathrm{C}$ to inactivate the enzymes. The mixture was then cooled and centrifuged at $10000 \mathrm{rpm}$ for 20 mins. The resulted hydrolysate was then freezedried at $-54^{\circ} \mathrm{C}$ while the vacuum was set at 0.25 mbar.

\subsection{Proximate analysis of Brownstripe red snapper}

The moisture, ash, fat and crude protein contents of the Brownstripe red snapper were determined based on the standard AOAC (2012) procedures. The samples were analysed in triplicates and calculated according to dry weight basis using AOAC methods (AOAC, 2012).

\subsection{Determination of Brownstripe red snapper degree of hydrolysis}

Degree of hydrolysis of BRSPH was determined using trichloroacteic acid (TCA) method (Hoyle and Merritt, 1994). One gram of lyophilized FPH powder was determined through Kjeldahl method (AOAC, 2012). As for the $10 \%$ TCA soluble nitrogen determination, $1 \mathrm{~g}$ of lyophilized BRSPH powder was added into $10 \mathrm{~mL}$ distilled water to determine the degree of hydrolysis. Then, $10 \mathrm{~mL}$ of $20 \%$ TCA was added into the sample and mixed by vortex for $30 \mathrm{~s}$. The sample was then left to stand for 30 mins, to allow protein precipitation and centrifuged at $8000 \mathrm{rpm}$ for $5 \mathrm{mins}$ (High Speed centrifuges 1580R, Cryozen Co, Ltd, Korea). Protein content in the collected supernatant was then measured using Kjedahl method (AOAC, 2012). The protein content was calculated using the formula:

$$
\begin{gathered}
\% \text { nitrogen }=\frac{m \mathrm{H} \mathrm{H}_{2} \mathrm{SO}_{4}(\text { sample }- \text { blank }) \times 1.4}{\text { weight sample }(\mathrm{g}) \times 1000} \times 100 \\
\% \text { Crude protein }=\% \text { nitrogen } \times 6.25
\end{gathered}
$$

The degree of hydrolysis was calculated using the formula below:

$$
\text { Degree of hydrolysis }(\%)=\frac{10 \% \text { TCA soluble nitrogen in the sample }}{\text { Total nitrogen in the sample }} \times 100
$$

\subsection{Determination of Brownstripe red snapper protein} hydrolysate (BRSPH) functional groups

The functional groups of BRFPH were determined using FTIR Transmission (Nicolet iS10, Thermo 
Scientific, US); in which $5 \mathrm{mg}$ of BRSPH powder was mixed with $250 \mathrm{mg}$ of $\mathrm{KBr}(1: 50)$. The mixture was homogenized using agate mortar and pestle and then was pressed into pellet (1-2 mm thick films) with a 15-ton hydraulic press. The FTIR spectra were obtained from wavenumber of 600 to $4000 \mathrm{~cm}^{-1}$ during 64 scans with 2 $\mathrm{cm}^{-1}$ resolution. The resulting spectrum represents the molecular absorption and transmission which then create a molecular fingerprint of the sample (Zainol et al., 2017).

\subsection{Determination of BRSPH molecular weight}

The BRSPH were analysed for sodium dodecyl sulphate polyacrylamide electrophoresis (SDS-PAGE) (Zainol et al., 2020). SDS-PAGE gel used consisted of 2 layers of acrylamide gels namely resolving gel and stacking gel. The BRSPH sample was diluted in 5\% (w/ v) and mixed with $1: 1(\mathrm{v} / \mathrm{v})$ ratio loading buffer. The mixture was then heated in $90^{\circ} \mathrm{C}$ water bath for 10 mins and cooled immediately prior to loading. Sample and protein standard volumes of $25 \mu \mathrm{L}$ were loaded into individual wells and operated using a discontinuous tristricine buffer with $25 \mathrm{~mA} / \mathrm{gel}$ constant current and $100 \mathrm{~V}$ constant voltage for $1 \mathrm{hr}$. After electrophoresis, proteins were visualized by $0.1 \%(\mathrm{w} / \mathrm{v})$ Coomassie blue G250 staining and de-staining by soaking in several changes of $40 \%(\mathrm{v} / \mathrm{v})$ methanol and $10 \%(\mathrm{v} / \mathrm{v})$ acetic acid until significant clear bands were obtained. Broad protein markers ( 11 to $245 \mathrm{kDa}$ ) were used for molecular weight comparison.

\subsection{Oil holding capacity of BRSPH}

Palm oil of $10 \mathrm{~mL}$ was added to $0.5 \mathrm{~g}$ BRFPH and centrifuged in $2000 \mathrm{RCF}$ for $30 \mathrm{mins}$ at $25^{\circ} \mathrm{C}$. The unbound oil was decanted off, and oil absorption capacity was determined from the difference in weight of the hydrolysate samples and expressed as gram of oil bound per gram sample (Shahidi et al., 1995).

\subsection{Development of battered squid containing BRSPH}

Table 1 shows the batter formulation prepared using the modified formulation of Shih et al. (2004). Five batter formulations were prepared with the addition of four different amount of BRSPH protein hydrolysate
$(2 \%, 4 \%, 6 \%$, and $8 \%)$ into each formulation and the other one batter formulation was kept constant in which no fish protein hydrolysate was added into the formulation. Then, squid flesh $(3 \mathrm{~cm} \times 3 \mathrm{~cm})$ was coated with the 5 batter formulations.

\subsection{Deep fat frying}

The coated squids were then deep-fried in palm oil for 3 mins at $180^{\circ} \mathrm{C}$. The excess oil was then drained the excess oil and cooled to room temperature. Then, the batter crust was peeled off from the squids and the oil was extracted using Soxhlet extraction method Hau et al. (2018).

\subsection{Determination of oil uptake}

Oil-uptake was measured according to a method described by Wasswa et al. (2007) with a slight modification. In a $50 \mathrm{~mL}$ centrifuge tube, a total of $0.5 \mathrm{~g}$ of BRSPH powder sample was added to $9 \mathrm{~g}$ of palm oil, mixed with a vortex mixer for $1 \mathrm{~min}$, and then centrifuged at room temperature at $2000 \mathrm{x} g$ for $30 \mathrm{mins}$. The weight of the extracted oil was determined from the hydrolysate. The difference between the oil weights derived from the hydrolysate and the initial palm oil $9 \mathrm{~g}$ was the oil weight consumed by a sample of $1 \mathrm{~g}$. The oil consumption was measured as the quantity of oil consumed by the samples.

\subsection{Texture profile analysis}

Texture profile analysis was performed using Dogan et al. (2005) method with a slight modification. The texture of the samples' crust was analysed in terms of hardness and crispness. Such analyses were measured in the fried samples using texture analyser (TA.XT. plus Stable Micro System Ltd., US). A load cell of $50 \mathrm{~N}$ was used. A conical probe was attached to the instrument for the penetration test. The instrument was set to a speed of $55 \mathrm{~mm}$ min-1 for $25 \%$ penetration of a conical probe into the fried sample.

\subsection{Colour profile analysis}

The crust colour of fried squid was determined using a colorimeter (Minolta CR 300, Japan), according to the CIE L* $a^{*} b^{*}$ scale. The colour reading included

Table 1. The percentage of ingredients in batter powder formulation

\begin{tabular}{lccccc}
\hline Ingredients & \multicolumn{5}{c}{ Percentage of ingredients (\%) } \\
\hline Fish protein hydrolysate & 0 & 2 & 4 & 6 & 8 \\
Wheat flour & 15.2 & 13.2 & 11.2 & 9.2 & 7.2 \\
Rice flour & 80 & 80 & 80 & 80 & 80 \\
Sodium chloride & 3 & 3 & 3 & 3 & 3 \\
Sodium bicarbonate & 1 & 1 & 1 & 1 & 1 \\
Disodium pyrophosphate & 0.8 & 0.8 & 0.8 & 0.8 & 0.8 \\
\hline
\end{tabular}

* Batter powder was mixed with water in the ratio of $1: 1$ 
lightness $\left(\mathrm{L}^{*}\right)$, redness $\left(\mathrm{a}^{*}\right)$, and yellowness $\left(\mathrm{b}^{*}\right)$. A standard white plate $(\mathrm{X}=91.98, \mathrm{Y}=93.97$, and $\mathrm{Z}=$ 110.41) was used to calibrate the instrument. Each sample was individually measured in triplicate.

\subsection{Sensory evaluation}

A fresh batch of fried squid was used for sensory studies. The deep-fried battered squid was subjected to sensory evaluation for colour, odour, oiliness, crispness, and overall acceptability. The sensory evaluation was carried out by thirty panellists using a 7-point hedonic scale from 1 to $7(1=$ dislike extremely, $2=$ dislike very much, 3 = like slightly, $4=$ neither like nor dislike, $6=$ like very much, $7=$ like extremely) (Mau et al., 2017). The sample was packed and coded with a 3 digit code. The coded samples were served in a tray to the panellist (Lawless and Heymann, 2010). The mean score for each attribute was reported.

\subsection{Statistical analysis}

Analysis of oil uptake was conducted triplicate and the statistical analysis was carried out using MINITAB 14 statistical software packaged. The results were expressed as mean \pm standard deviation. The significant difference at $(\mathrm{p}<0.05)$ was performed by one-way analysis of variance (ANOVA) and Fisher's Least Significant Difference (LSD) test (Mamat et al., 2018).

\section{Results and discussion}

\subsection{Chemical composition of raw material}

As shown in Table 2, fresh Brownstripe red snapper mince contained $17.34 \%$ crude protein, $77.90 \%$ moisture and $5.43 \%$ crude fat. Crude protein level was within the range based on a previous study (Benjakul et al., 2009). The fishes of the family Lutjanidae demonstrated that the average moisture content was between 71 and $75 \%$, fresh Brownstripe red snapper mince was out of this range, indicating that chemical composition of fish varies within and between species.

\subsection{Protein content and degree of hydrolysis (DH) of Brownstripe red snapper protein hydrolysates (BRSPH)}

Table 2 also shows that as predicted protein hydrolysate exhibited higher protein content (38.71\%) compared to the fresh Brownstripe red snapper mince $(17.34 \%)$ and could be an essential protein source. The high protein content could have resulted from the solubilisation of protein during hydrolysis, the removal of insoluble undigested non-protein substances and the partial removal of lipid after hydrolysis (Benjakul and Morrissey, 1997). The percentage of solubilised protein was found to be dependent on the amount of lipid in the raw material. Degree of hydrolysis (DH) is an important factor highly related to the hydrolytic process yield (Adler-Nissen, 1986). DH value of BRSPH was measured at $98.19 \%$. The data also suggested that the soluble protein also increased as the $\mathrm{DH}$ value increased. Nevertheless, it has been mentioned that DH has an impact on FPH's physicochemical properties (Harun et al., 2017), which could result in a low oil uptake.

Table 2. Chemical composition of Brownstripe red snapper fish edible flesh

\begin{tabular}{lc}
\hline Moisture content (\%) & $77.90 \pm 0.40$ \\
Protein (\%) & $17.34 \pm 0.72$ \\
Fat content (\%) & $5.43 \pm 0.03$ \\
Ash (\%) & $2.0 \pm 0.12$ \\
Degree of hydrolysis (\%) & $98.19 \pm 0.24$ \\
Protein in hydrolysate powder (\%) & $38.71 \pm 1.71$ \\
\hline
\end{tabular}

\subsection{Determination of functional groups of BRSPH}

Fourier Transform Infrared (FTIR) spectroscopy is an important and well-established technique to study the secondary structure of proteins and polypeptides. Amide I $\left(1700-1600 \mathrm{~cm}^{-1}\right)$ band is the most sensitive and widely used in studies of protein secondary structure. Amide I band is mainly due to $\mathrm{C}=\mathrm{O}$ stretching vibration (approximately 80\%) of the amide group coupled with in -plane $\mathrm{NH}$ bending (less than 20\%) (Kong and $\mathrm{Yu}$, 2007). Amide II (1575-1480 $\left.\mathrm{cm}^{-1}\right)$ derives mainly from in-plane $\mathrm{NH}$ bending and $\mathrm{CN}$ stretching vibration and shows less protein conformational sensitivity compared with amide I while other amide vibrational bands have less practical use in protein conformational studies (Kong and $\mathrm{Yu}, 2007$ ). The FTIR spectra (Figure 2) of BRSPH demonstrated the absorption band at $1559.46 \mathrm{~cm}$ ${ }^{-1}$ and $1647.62 \mathrm{~cm}^{-1}$ to $1652.39 \mathrm{~cm}^{-1}$ region, indicated the existence of amide II and amide I, respectively. Amide I bands of protein hydrolysate was found at $1630 \mathrm{~cm}^{-1}$ (Benjakul et al., 2009). Higher frequencies of amide I bands is attributed to greater loss of molecular order of triple helix due to uncoupling of intermolecular crosslinks and disruption of intramolecular bonding when protein hydrolysate was extracted at higher temperature or longer time (Ahmad and Benjakul, 2011).

\subsection{Molecular characterization of the BRSPH by SDS- $P A G E$}

Figure 3 shows the characterisation by SDS-PAGE of BRSPH's molecular weights (MW). SDS-PAGE is the most widely used for analysing protein mixture, monitoring protein purity and determining their molecular weights. Characterization of the molecular weights of BRSPH by SDS-PAGE showed the presence of strong bands ranging between $10-15 \mathrm{kDa}$ and $75-250$ $\mathrm{kDa}$, which indicated that Alcalase ${ }^{\circledR}$ enzyme was able to produce small-sized peptides in 180 mins. Several 


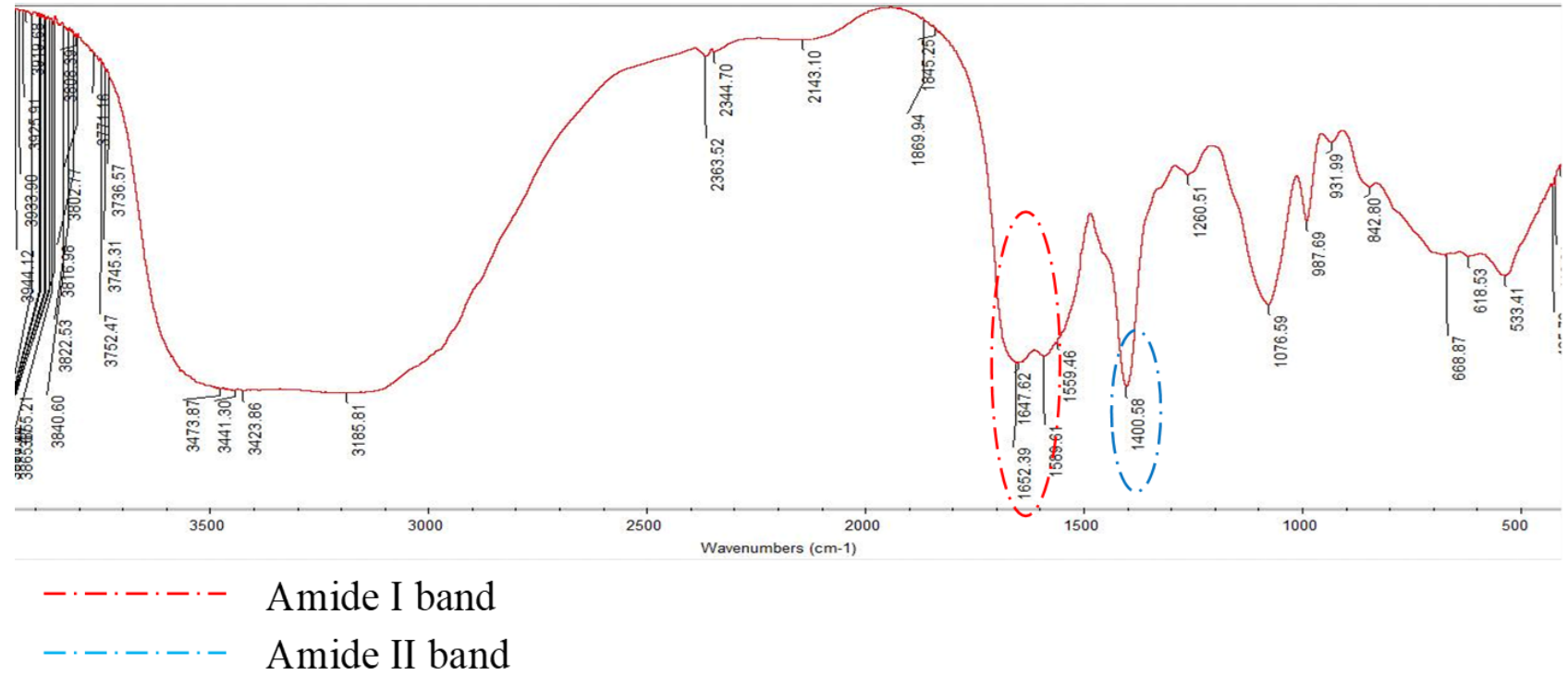

Figure 2. The FITR spectra of Brownstripe red snapper hydrolysate (BRSPH) powder

studies have shown Alcalase ${ }^{\circledR}$ 's ability to produce low molecular weight peptides via a high degree of hydrolysis (DH) (Liaset et al., 2000). This is in coincident with high DH of Brownstripe red snapper (98.18\%). According to Bhaskar et al. (2008), fish protein hydrolysate with high nutritional values should be rich in low molecular weight peptides, and the successful production of such desired peptides indicated its potential application in functional food products.

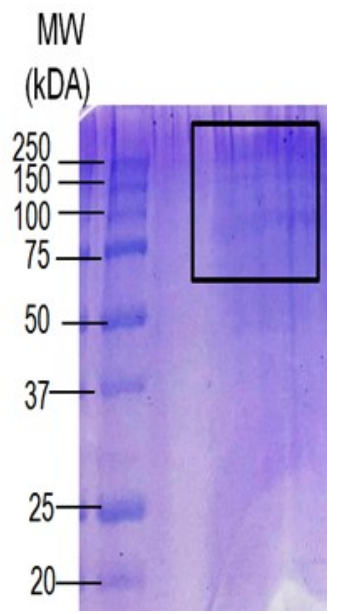

Figure 3. SDS-PAGE patterns of Brownstripe red snapper hydrolysate (BRSPH) powder

\subsection{Oil binding capacity}

Oil binding capacity expresses the quantity of oil which directly bound by the protein and is of great interest as it is an important functional characteristic, especially expected by meat and confectionery industries (Gbogouri et al., 2004). It is an important attribute that will influence the taste of a product, hence increasing the acceptance of the product. In this study, BRSPH powder exhibited oil binding capacity of $2.38 \mathrm{~g}$ oil $/ \mathrm{g}$ protein, which may be considered as low. The hydrolysates can be potentially used as functional ingredients for the meat and confectionary industry. The decrease in oil binding capacity as DH increased might have been due to the hydrolytic degradation of the protein structure itself. Oil binding capacity of proteins also correlates with surface hydrophobicity (Kristinsson and Rasco, 2000). Generally, fish protein hydrolysates may be expected to have significant changes in oil absorption, compared to those of native proteins or common food protein ingredients (Sathivel et al., 2003; Gbogouri et al., 2004).

\subsection{Analytical methods of batter crusts of fried squids}

\subsubsection{Colour profile}

Table 3 shows the effect of different amount of BRSPH on colour development of deep-fat-fried squid that was examined in terms of Hunter $L^{*} a^{*} b^{*}$ values. Deep-fat-fried foods develop a golden colour, between yellow and brown, when they are properly fried. This is a characteristic that consumers normally consider very attractive. A light golden tone is the benchmark colour for determining the end of the final frying process. A brownish yellow colour is the benchmark colour for the deep-fat-fried squids in this study. There was no significant trend in the variation of the lightness $\left(\mathrm{L}^{*}\right)$ with an increased amount of BRSPH in the batter. When the frying time was extended longer, the $L^{*}$ value decreased at all the frying temperatures. At the same frying time, the higher frying temperature provided the lower $L *$ value. The decrease in $L *$ value has been linked with non-enzymatic browning reactions which accelerate at high temperatures (Dueik et al., 2010). Dogan et al. (2005) also reported that the colour of deep-fat fried chicken nuggets was studied by they found that as frying time increased, $\mathrm{L}^{*}$ values decreased. Therefore, the insignificant differences in $L^{*}$ values can be explained by the consistent frying time ( 3 mins) carried out in the frying process. Redness ( $\left.a^{*}\right)$ is not a desirable colour in fried food products (Ansarifar et al., 2012). The changes in $\mathrm{a}^{*}$ values were mainly related to myoglobin oxidation 
Table 3. Colour profile ( $\left.\mathrm{L}^{*}, \mathrm{a}^{*}, \mathrm{~b}^{*}\right)$ of deep-fat-fried squids incorporated with different amount of BRSPH

\begin{tabular}{cccccc}
\hline Percentage of hydrolysate added & $0 \%$ & $2 \%$ & $4 \%$ & $6 \%$ & $8 \%$ \\
\hline L* (Lightness) $^{*}$ (Redness) & $1.71 \pm 0.17^{\mathrm{a}}$ & $2.71 \pm 0.08^{\mathrm{a}}$ & $4.69 \pm 0.07^{\mathrm{b}}$ & $4.62 \pm 0.19^{\mathrm{b}}$ & $5.09 \pm 0.05^{\mathrm{b}}$ \\
$\mathrm{a}^{*}$ (Yellowness) & $20.68 \pm 0.41^{\mathrm{a}}$ & $20.79 \pm 0.26^{\mathrm{a}}$ & $21.09 \pm 0.52^{\mathrm{a}}$ & $21.14 \pm 0.03^{\mathrm{a}}$ & $21.30 \pm 0.73^{\mathrm{a}}$ \\
$\mathrm{b}^{*}$ (Yellow & $66.79 \pm 0.47^{\mathrm{a}}$ & $66.69 \pm 0.08^{\mathrm{a}}$ & $67.16 \pm 0.58^{\mathrm{a}}$ & $66.34 \pm 0.01^{\mathrm{a}}$ \\
\hline
\end{tabular}

Values are mean \pm standard deviation of three replications. Values with same superscript letters within the same row are not significantly different $(\mathrm{p}<0.05)$.

(Pilar and Reyes, 2007). Deep-fat-fried squid without BRSPH has significantly lower $a^{*}$ value compared to deep-fat-fried squid incorporated with $2 \%, 4 \%, 6 \%$ and $8 \%$ of BRSPH. Addition of $8 \%$ BRSPH provided the highest $\mathrm{a}^{*}$ value (highest redness) indicated that the development of golden brown to dark brown colour in deep-fat-fried squids due to non-enzymatic browning reactions (Garayo and Moreira, 2002). Mohamed et al. (1988) also observed that the addition of ovalbumin to a batter improved crispness and colour owing to the amine groups present in proteins participating in the Maillard reaction. For yellowness, no significant difference was observed between control and deep-fat-fried squids incorporated BRSPH. This could be due to the consistent frying time (3 mins) carried out in this study. Ansarifar et al. (2012) reported that $b^{*}$ value of deep-fat-fried crust decreased with frying time which implied that frying time has a significant effect on the yellowness of the fried product.

\subsubsection{Texture profile analysis}

The texture profiles of the deep-fat-fried squids which include hardness and crispness were assessed in this study. The addition of BRSPH produces higher hardness compared to the control and $6 \%$ added BRSPH to the batter showed the highest value compared to all other treatments. This result was identical to those reported by Mohamed et al. (1988), indicating that the addition of protein, such as egg yolk to the batter has reported improving the hardness of fried batter. Crispness was described as the most versatile single texture parameter of a product because it was universally liked, it enhanced or contrasted texture, and was the prominent texture attribute related to top-quality cooking. Deep-fat-fried squid without BRSPH showed the least crispness $(3.52 \mathrm{~kg} . \mathrm{s})$ among all samples. Incorporation of BRSPH could be the cause of increased crispness in deep-fat-fried squid batter crust and this is in the agreement with Mohamed et al. (1988), denoting that the addition of protein, ovalbumin to a batter improved crispness.

\subsubsection{Oil uptake analysis}

Oil uptake of deep-fat-fried squid batter crust incorporated with $0 \%, 2 \%, 4 \%, 6 \%, 8 \% \mathrm{BRSPH}$ is shown in Table 4. The oil uptake of deep-fat-fried squid batter crust incorporated with $8 \%$ BRSPH was significantly the lowest $(23.30 \%)$ among the samples. These results indicated that the higher the BRSPH, the lower the oil absorption. Oil uptake of deep-fat-fried squid batter crust incorporated with $2 \%, 4 \%, 6 \%$ was significantly lower than the control sample, which also demonstrated that the oil uptake of the control sample was the highest among samples. This result suggested that FPH was able to reduce fat uptake when applied to the batter system of deep-fried battered food products as a functional food ingredient. Oil uptake reduction of deep-fried food using other protein based ingredients in batter coating has also been reported before. Albert and Mittal (2002), found that batter coating systems of soy protein "isolate"/methyl cellulose could reduce the fat uptake of deep-fried cereal products by up to $99.8 \%$.

\subsubsection{Sensory evaluation of deep-fat-fried squids}

The sensory panels were convened to assess the effects on the colour, crispness, oiliness, taste and overall acceptability of deep-fat-fried squid incorporated with $0 \%, 2 \%, 4 \%, 6 \%$, and $8 \%$. Garcia et al. (2002) compared the effects of various cellulose derivatives and additionally the sorbitol effect on selected cellulose derivatives in French fries and found that a fat uptake reduction of $41 \%$ could be achieved (Table 5). The deepfat-fried squids with added $4 \%, 6 \%$ and $8 \%$ of BRSPH produced higher colour scores than the control $(\mathrm{p}<0.05)$.

Table 4. The oil uptake, hardness and crispness values of deep-fat-fried squid batter crust incorporated with different amount of BRSPH

\begin{tabular}{cccccc}
\hline Amount of Tooth-pony FPH in Batter & $0 \%$ & $2 \%$ & $4 \%$ & $6 \%$ & $8 \%$ \\
\hline Oil uptake (\%) & $30.15 \pm 1.35^{\mathrm{a}}$ & $28.20 \pm 0.13^{\mathrm{b}}$ & $27.67 \pm 0.31^{\mathrm{b}}$ & $27.39 \pm 0.52^{\mathrm{b}}$ & $23.30 \pm 0.61^{\mathrm{c}}$ \\
Hardness (kg) & $0.02 \pm 0.01^{\mathrm{b}}$ & $0.03 \pm 0.01^{\mathrm{ab}}$ & $0.04 \pm 0.01^{\mathrm{a}}$ & $0.04 \pm 0.01^{\mathrm{a}}$ & $0.03 \pm 0.01^{\mathrm{ab}}$ \\
Crispness (kg.sec) & $3.52 \pm 0.01^{\mathrm{b}}$ & $3.55 \pm 0.01^{\mathrm{ab}}$ & $3.57 \pm 0.02^{\mathrm{a}}$ & $3.57 \pm 0.01^{\mathrm{a}}$ & $3.59 \pm 0.01^{\mathrm{a}}$ \\
\hline
\end{tabular}

Values with same superscript letters within the same row are not significantly different $(\mathrm{p}<0.05)$. 
Table 5. Sensory scores of deep-fat-fried squid incorporated with $0 \%, 2 \%, 4 \%, 6 \%$ and $8 \%$ of BRSPH

\begin{tabular}{cccccc}
\hline & Colour & Crispness & Oiliness & Taste & Overall acceptability \\
\hline $0 \%$ & $4.33 \pm 1.92^{\mathrm{b}}$ & $4.00 \pm 1.68^{\mathrm{a}}$ & $4.33 \pm 1.83^{\mathrm{ab}}$ & $4.47 \pm 1.93^{\mathrm{b}}$ & $5.07 \pm 1.20^{\mathrm{ab}}$ \\
$2 \%$ & $4.63 \pm 1.56^{\mathrm{ab}}$ & $3.50 \pm 1.68^{\mathrm{a}}$ & $3.57 \pm 1.57^{\mathrm{b}}$ & $4.50 \pm 1.48^{\mathrm{b}}$ & $4.70 \pm 1.37^{\mathrm{b}}$ \\
$4 \%$ & $5.20 \pm 1.16^{\mathrm{a}}$ & $4.23 \pm 1.65^{\mathrm{a}}$ & $4.70 \pm 1.51^{\mathrm{a}}$ & $5.43 \pm 1.19^{\mathrm{a}}$ & $5.43 \pm 0.93^{\mathrm{a}}$ \\
$6 \%$ & $5.30 \pm 1.42^{\mathrm{a}}$ & $4.20 \pm 1.73^{\mathrm{a}}$ & $3.93 \pm 1.68^{\mathrm{ab}}$ & $5.17 \pm 1.53^{\mathrm{ab}}$ & $4.97 \pm 1.25^{\mathrm{ab}}$ \\
$8 \%$ & $5.10 \pm 1.24^{\mathrm{a}}$ & $4.17 \pm 1.95^{\mathrm{a}}$ & $3.93 \pm 1.76^{\mathrm{ab}}$ & $5.13 \pm 1.38^{\mathrm{ab}}$ & $4.93 \pm 1.14^{\mathrm{ab}}$ \\
\hline
\end{tabular}

Values are mean \pm standard deviation of three replications. Values with same superscript letters within the same row are not significantly different $(\mathrm{p}<0.05)$.

Taste scores were increased by the addition of BRSPH. The samples with $4 \%$ BRSPH showed the highest taste scores than that of other samples. Maillard is a nonenzymatic browning reaction, which causes the decomposition of certain amino acids (the building blocks of proteins), in the presence of reducing sugars. This reaction leads to the formation of brown pigments, or melanoidins, which are not well defined and may result in numerous flavour and odour compounds (deMan, 1999).

Textural quality is an important attribute for the acceptability of fries and it is influenced by both material and process conditions (Troncoso et al., 2009). A longer frying time benefits for getting a crisper fried food. In the present study, crispiness values were not significant differences between the five samples. This was probably due to the consistent frying time ( 3 mins) carried out in this study. Addition of different proteins at different concentrations to the batter decreased the oil content of the final product. Less oil absorption may be related to the formation of covalent links within films during heating. The reduced oil uptake may also be related to thermal gelation and the film-forming ability of proteins. Ovalbumin, the main protein in egg albumen, was also reported to reduce the oil uptake of the fried product, probably owing to its lipophobic nature (Kato and Nakai, 1980). However, panels perceived that the deep-fat-fried squid batter with $4 \%$ BRSPH added had undesirable oiliness.

Overall, with regard to the flavour and crispness characteristics, the samples with 4\% BRSPH exhibited the highest acceptability scores than that of other samples. Enzymatic hydrolysis of protein develops formation of short chain peptides, thus causing development of bitter taste in the product (Kristinsson and Rasco, 2000). However, the lowest molecular weight of BRSPH was in the range of $10-15 \mathrm{kDa}$, indicating that the presence of higher amount (4\%) of BRSPH did improve the taste and overall acceptability of deep-fatfried squid instead of generating bitterness. These findings are in concert with the study by Hoyle and Merritt (1994), who reported that Alcalase ${ }^{\circledR}$-hydrolyzed herring with a higher DH generated less bitter taste hence giving the higher sensory score. The high acceptability scores of deep-fat-fried squid incorporated with $4 \%$ of BRSPH could be explained by umami taste existed in FPH. Umami was one of the dominant tastes of threadfin bream hydrolysates produced by Alcalase ${ }^{\circledR}$ (Normah et al., 2004).

\section{Conclusion}

This study shows that oil uptake of batter crust incorporated with $2 \%, 4 \%$ and $6 \%$ of BRSPH exhibited significant differences $(p<0.05)$ compared with the control sample $(30.15 \%)$. In sensory evaluation, with regard to the flavour and crispness characteristics, the samples with $4 \%$ of BRSPH had the highest overall acceptability scores than other samples. In general, sensory evaluations indicated that deep-fat-fried squids with BRSPH were accepted. Thus, the inclusion of BRSPH may offer better colour and flavour of the deepfat-fried squids, thereby improving the overall acceptability of deep-fat-fried squids.

\section{Conflict of interest}

The authors declare that there is no conflict of interest in conducting this study.

\section{Acknowledgments}

This research was supported by Universiti Malaysia Terengganu. The authors would like to thank the central lab of UMT and the Faculty of Fisheries and Food Science (FPSM) for the facilities provided to conduct the study.

\section{References}

Adler-Nissen, J. (1986). Relationship of structure to taste of peptides and peptide mixtures. In Feeney, R.E. and Whitaker, J.R. (Eds.). Protein tailoring for food and medical uses, p. 97-122. New York, USA: Marcel Dekker.

Ahmad, M. and Benjakul, S. (2011). Characteristics of gelatine from the skin of unicorn leatherjacket (Aluterus monoceros) as influenced by acid 
pretreatment and extraction time. Food Hydrocolloid, 25(3), 381-388. https:// doi.org/10.1016/j.foodhyd.2010.07.004.

Albert, S. and Mittal, G.S. (2002). Comparative evaluation of edible coatings to reduce fat uptake in a deep-fat fried cereal product. Food Research International, 35(5), 445-458. https:// doi.org/10.1016/S0963-9969(01)00139-9.

Ansarifar, E., Mohebbi, M. and Shahidi, F. (2012). Studying some physicochemical characteristics of crust coated with white egg and chitosan using a deep-fried model system. Food and Nutrition Sciences, 3(5), 685-692. https://doi.org/10.4236/ fns.2012.35093.

AOAC. (2012). Official methods of analysis, Association of official analytical chemist. 19th ed. Washington D.C., USA: AOAC

Benjakul, S. and Morrissey, M.T. (1997). Protein hydrolysates from Pacific whiting solid wastes. Journal of Agricultural and Food Chemistry, 45(9), 3423-3430. https://doi.org/10.1021/jf970294g.

Benjakul, S., Oungbho, K., Visessanguan, W., Thiansilakul, Y. and Roytrakul, S. (2009). Characteristics of gelatine from the skins of bigeye snapper, Priacanthus tayenus and Priacanthus macracanthus. Food Chemistry, 116(2), 445-451. https://doi.org/10.1016/j.foodchem.2009.02.063.

Bhaskar, N. and Mahendrakar, N.S. (2008). Protein hydrolysate from visceral waste proteins of Catla (Catla catla): Optimization of hydrolysis conditions for a commercial neutral protease. Bioresource Technology, 99, 4105-4111. https://doi.org/10.1016/ j.biortech.2007.09.006

deMan, J.M. (1999). Relationship among chemical, physical, and textural properties of fats. In Widlak, N. (Ed.). Physical properties of fats, oils and emulsions, p. 79-95. Champaign, IL, USA: AOCS Press.

Dogan, S.F., Sahin, S. and Sumnu, G. (2005). Effects of batters containing different protein types on the quality of deep-fat-fried chicken nuggets. European Food Research and Technology, 220(5-6), 502-508. https://doi.org/10.1007/s00217-004-1099-7.

Dueik, V., Robert, P. and Bouchon, P. (2010). Vacuum frying reduces oil uptake and improves the quality parameters of carrot crisps. Food Chemistry, 119(3), 1143-1149. j.foodchem.2009.08.027.

Garayo, J. and Moreira, R.G. (2002). Vacuum frying of potato chips. Journal of Food Engineering, 55(2), 181-191. https://doi.org/10.1016/S0260-8774(02) 00062-6.
Garcia, M.A., Ferrero, C., Bertola, N., Martino, M. and Zaritzky, N. (2002). Edible coating from cellulose derivatives to reduce oil uptake in fried products. Innovative Food Science and Emerging Technology, 3(4), 391-397. https://doi.org/10.1016/S1466-8564 (02)00050-4.

Gbogouri, G.A., Linder, M., Fanni, J. and Parmentier, M. (2004). Influence of hydrolysis degree on the functional properties of Salmon by-product hydrolysates. Journal of Food Science, 69(8), 615622. https://doi.org/10.1111/j.13652621.2004.tb09909.x.

Harun, Z., Amiza, M.A., Sarbon, N.M. and Zainol, M.K.M. (2017). Optimisation of enzymatic protein hydrolysis of Mud Crab (Scylla sp.) to obtain maximum Angiotensin-Converting enzyme inhibitory (ACEI) activity using response surface methodology. Malaysian Applied Biology, 46(3), 3340.

Hau, E.H., Amiza, M.A., Mohd Zin, Z. and Zainol, M.K. (2018). The properties, compositions and qualities of Yellowstripe scad (Selaroides leptolepis) and its liquid protein hydrolysate based on different enzyme concentrations, hydrolysis time and choice of buffer. International Food Research Journal, 25(3), 11741180.

Hoyle, N.T. and Merrltt, J.H. (1994). Quality of fish protein hydrolysates from Herring (Clupea harengus). Journal of Food Science, 59(1), 76-79. https://doi.org/10.1111/j.1365-2621.1994.tb06901.x.

Kato, A. and Nakai, S. (1980). Hydrophobicity determined by a fluorescence probe method and its correlation with surface properties of proteins. Biochimica et Biophysica Acta (BBA) - Protein Structure, $\quad 624(1), \quad$ 13-20. https:// doi.org/10.1016/0005-2795(80)90220-2.

Kong, J. and $\mathrm{Yu}, \mathrm{S}$. (2007). Fourier transform infrared spectroscopic analysis of protein secondary structures. Acta Biochimica et Biophysica Sinica, 39 (8), 549-559. https://doi.org/10.1111/j.17457270.2007.00320.x.

Kristinsson, H.G. and Rasco, B.A. (2000). Fish protein hydrolysates: Production, biochemical and functional properties. Critical Reviews in Food Science and Nutrition, 40(1), 43-81. https:// doi.org/10.1080/10408690091189266.

Lawless, H.T. and Heymann, H. (2010). Sensory evaluation of food: Principles and Practices, p. 1471. USA: Springer. https://doi.org/10.1007/978-14419-6488-5

Liaset, B., Lied, E. and Espe, M. (2000). Enzymatic hydrolysis of by-products from the fish-filleting 
industry; chemical characterisation and nutritional evaluation. Journal of the Science of Food and Agriculture, 80(5), 581-589. https://doi.org/10.1002/ (sici)1097-0010(200004)80:53.0.co;2-i.

Lumanlan, J.C., Fernando, W.M.A.D.B. and Jayasena, V. (2019). Mechanisms of oil uptake during deep frying and applications of pre-drying and hydrocolloids in reducing fat content of chips. International Journal of Food Science and Technology, 55(4), 1661-1670. https:// doi.org/10.1111/ijfs.14435.

Mamat, H., Akanda, J.M.H., Zainol, M.K. and Yu, A.I. (2018). The influence of seaweed composite flour on the physicochemical properties of muffin. Journal of Aquatic Food Product Technology, 27(5), 635-642, https:// doi.org/10.1080/10498850.2018.1468841.

Mau, J.-L., Lee, C.-C., Chen, Y.-P. and Lin, S.-D. (2017). Physicochemical, antioxidant and sensory characteristics of chiffon cake prepared with black rice as replacement for wheat flour. LWT - Food Science and Technology, 75, 434-439. https:// doi.org/10.1016/j.lwt.2016.09.019.

Mellema, M. (2003). Mechanism and reduction of fat uptake in deep-fat fried foods. Trends in Food Science and Technology, 14(9), 364-373. https:// doi.org/10.1016/S0924-2244(03)00050-5.

Mohamed, S., Hamid, N.A. and Hamid, M.A. (1998). Food components affecting the oil absorption and crispness of fried batter. Journal of Science and Food Agriculture, 78(1), 39-45. https:// doi.org/10.1002/(SICI)1097-0010(199809) 78:13.0.CO;2-G.

Normah, I., Jamilah, B., Saari, N. and Che Man, Y.B. (2004). Chemical and taste characteristics of threadfin bream (Nemipterus japonicus) hydrolysate. Journal of Science and Food Agriculture, 84(11), 1290-1298. https://doi.org/10.1002/jsfa.1743.

Pedreschi, F. and Moyano, P. (2005). Effect of predrying on texture and oil uptake of potato chips. LWT-Food Science and Technology, 38(6), 599-604. https://doi.org/10.1016/j.lwt.2004.08.008.

Pilar, T. and Reyes, P. (2007). Simultaneous application of transglutaminase and high pressure to improve functional properties of chicken meat gels. Food Chemistry, 100(1), 264-272. https://doi.org/ 10.1016/ j.foodchem.2005.09.058.

Radwan, Y.O. (2017). Application of hydrocolloids as coating films to reduce oil absorption in fried potato chip-based pellets. Pakistan Journal of Nutrition, 16 (10), 805-812. https://doi.org/10.3923/ pjn.2017.805.812.

Rosmilah, M., Shahnaz, M., Masita, A., Noormalin, A. and Jamaludin, M. (2005). Identification of major allergens of three species of local snappers: Lutjanus argentimaculatus (merah/red snapper) and Lutjanus johnii (jenahak/golden snapper). Tropical Biomedicine, 22(2), 171-177.

Sathivel, S., Bechtel, P.J., Babbitt, J., Smiley, S., Crapo, C., Reppond, K.D. and Prinyawiwatkul, W. (2003). Biochemical and functional properties of Herring (Clupea harengus) by-product hydrolysates. Journal of Food Science, 68(7), 2196-2200. https:// doi.org/10.1111/j.1365-2621.2003.tb05746.x.

Shahidi, F., Han, X.Q. and Synowiecki, J. (1995). Production and characteristics of protein hydrolysates from capelin (Mallotus villosus). Food Chemistry, 53(3), 285-293. https:// doi.org/10.1016/0308-8146(95)93934-J.

Shih, F.F., Boue, S.M., Daigle, K.W. and Shih, B.Y. (2004). Effects of flour sources on acrylamide formation and oil uptake in fried batters. Journal of the American Oil Chemists' Society, 81(3), 265-268. https://doi.org/10.1007/s11746-004-0893-8.

Tanuja, S., Haridas, A., Zynudheen, A.A. and Joshy, C.G. (2014). Functional and antioxidative properties of fish protein hydrolysate (FPH) produced from the frame meat of striped catfish Pangasianodon hypophthalmus (Sauvage, 1878) using alkaline protease alcalse. Indian Journal Fish, 61(2), 82-89.

Troncoso, E. and Pedreschi, F. (2009). Modelling water loss and oil uptake during vacuum frying of pretreated potato slices. LWT-Food Science and Technology, 42(6), 1164-1173. https:// doi.org/10.1016/j.lwt.2009.01.008.

Wasswa, J., Tang, J., Gu, X. and Yuan, X. (2007). Influence of the extent of enzymatic hydrolysis on the functional properties of protein hydrolysate from grass carp (Ctenopharyngodon idella) skin. Food Chemistry, 104(4), 1698-1704. https:// doi.org/10.1016/j.foodchem.2007.03.044.

Zainol, M.K., Tan, R.C., Mohd Zin, Z., Ahmad, A. and Danish-Daniel, M. (2020). Effectiveness of Toothpony (Gazza minuta) protein hydrolysate on reducing oil uptake upon deep-frying. Food Research, 4(3), 805 - 813. https://doi.org/10.26656/ fr.2017.4(3).392.

Zainol, M.K., Lew, H.W., Mohd Fauzi, N.I., Ng, K.S., Razman, N., Kadimi, N.F., Zamri, A.I., Mohd Zin, Z., Fisal, A., Chilek, T.Z.T. and Mamat, H. (2017). Antioxidative properties of selected microencapsulated plants powder prepared using ultrasonic spray-drying technique. Malaysian Applied Biology, 46(3), 41-49. 